The BDJ News section accepts items that include general news, latest research and diary events that interest our readers. Press releases or articles may be edited, and should include a colour photograph if possible. Please direct your correspondence to the News Editor, Arveen Bajaj at the BDJ, The Macmillan Building, 4 Crinan Street, London N1 9XW or by email to bdj@bda.org

\section{Tooth whitening statement updated}

The GDC's Professional Standards Directorate has updated the Council's statement on tooth whitening following regular queries from dentists and patients.

The statement says that under current cosmetics regulations, tooth whitening products need to be handled with caution as they contain bleach.

According to the terms of the Cosmetic Products (Safety) Regulations it is illegal for tooth whitening products to be supplied which contain more than $0.1 \%$ hydrogen peroxide or for any associated products which release greater than this level of hydrogen peroxide to be supplied.

The GDC adds that it does not prosecute dentists or anyone else in the criminal courts for breach of the cosmetics regulations, rather it is Local Trading Standards officers who are responsible for the enforcement of these regulations.

It is also aware that the national coordinating authority for Trading Standards has advised officers to take a 'low-key' approach to the enforcement of the cosmetics regulations, because they and the Department of Trade and Industry recognise that the current legal limit is much too low, and this is widely recognised within the Member States of the European Union.

It adds that all queries about prosecution policy should be directed to your local Trading Standards office.

The updated GDC statement also looks at the prosecution for breach of the cosmetics regulations, ethnical considerations and indemnity cover. For more information please contact the GDC.

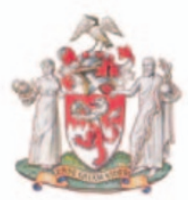

General Dental Council

\section{Website launch}

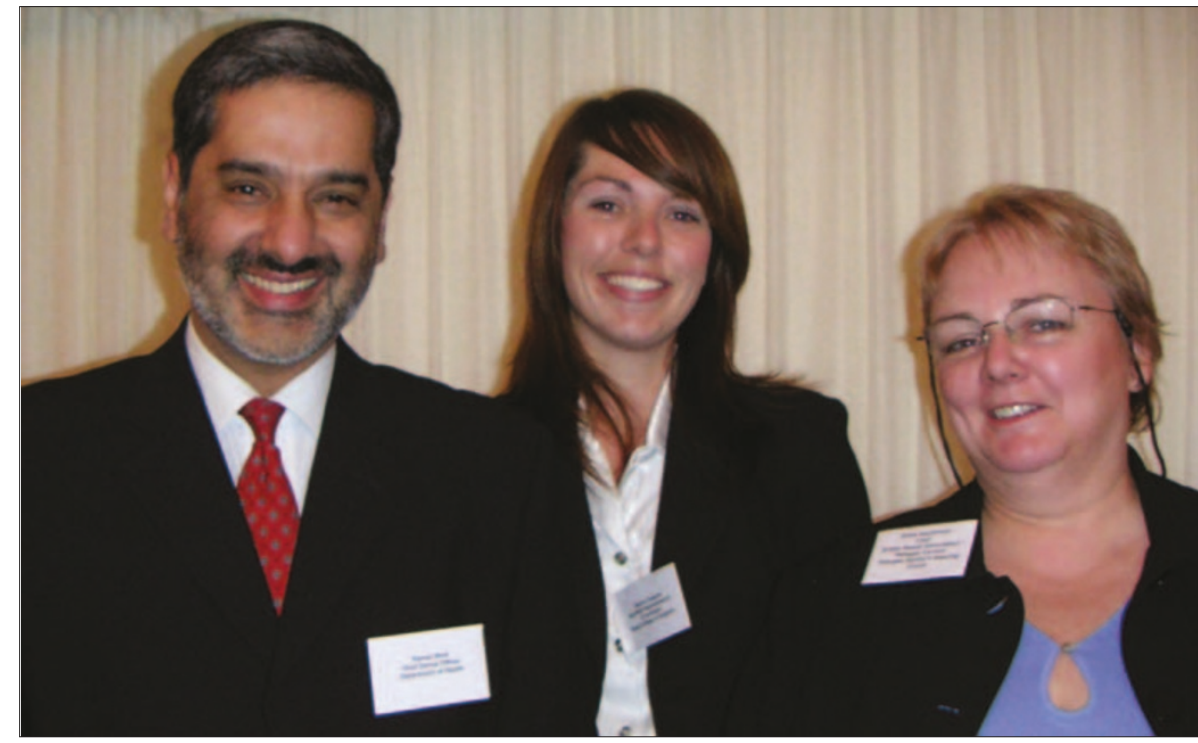

A new website designed to support refugee and overseas qualified health professionals who are settled in the UK return to work in health and social care (ROSE) was recently launched in London. The website is being developed by a partnership of organisations, led by the North East London Strategic Health Authority (NELSHA) and including NHS Trusts, the voluntary sector and higher education institutions. Held at the House of Lords, the launch was hosted by Baroness Murphy of Aldgate, Chairman of NELSHA, and speakers included Professor Raman Bedi, Chief Dental Officer (England) and Susie Sanderson, Vice Chair British Dental Association. Pictured from left to right, Professor Raman Bedi, Sharon Coppard, Administrator National Advice Centre for Postgraduate Dental Education and Susie Sanderson of the British Dental Association. For more information visit www.rose.nhs.uk

\section{Australian appointment}

Professor Newell Johnson has been appointed Dean and Head of School at Griffith University's School of Dentistry and Oral Health in Australia. He will take up the position at the University's Gold Coast campus in March 2005.

Professor Johnson is head of the Oral Health Research Group at KCL Dental Institute and Director of the World Health Organisation (WHO) Collaborating Centre for Oral Cancer and Precancer. His clinical research includes the areas of head and neck cancers, and oral aspects of HIV/AIDS and he has developed active research projects in Africa and India. He is also President of the British Society for Dental Research and of the Section of Odon-

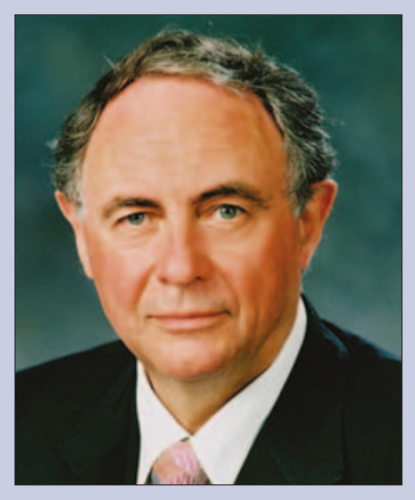
tology of the Royal Society of Medicine. He was awarded the John Tome's Medal for outstanding services to the profession and the British Dental Association in 2004.

It is hoped that his appointment to Griffith University will provide the opportunity to develop new relationships particularly in rural and remote communities of Australia and outwards to regional neighbours including Papua New Guinea and the Pacific Islands. 


\section{DIARY}

March 2005

83rd General Session \& Exhibition of the IADR, 34th Annual Meeting of the AADR, 29th Annual Meeting of the CADR

Date: 9-12.03.05

Venue: Baltimore Convention Centre www.dentalresearch.org

The Junior Trainees Group of the British Association of Oral \& Maxillofacial Surgeons 11 th Annual Meeting

Date: 11-12.03.05

Venue: City Hospital, Birmingham www.baoms.org.uk/meetings/BAOMS_ms g_programme.pdf

\section{April 2005}

Academy of Laser Dentistry Source 2005: Lasers in Dentistry

Date: 6-9.04.05

Venue: New Orleans Marriott Hotel, New Orleans, Louisiana, USA

Tel: 1-877-527-3776

Email: memberservices@

laserdentistry.org

www.source2005.org

Irish Dental Association Annual Scientific Conference

Date: 14-16.04.05

Venue: Killarney, Ireland

Tel: 0035312830499

Email: info@irishdentalass.ie

IDS International Dental Show

Date: 12-16.04.05

Venue: Cologne

Tel: +44 01604 - 621014

Fax: +4408709909523

Email: tradefairs@yorks-travel.co.uk www.idfdentalconference.com

FGDP UK and FDS Dentists with a Special Interest

Date: 21.04.05

Venue: The Royal College of Surgeons of England, London

Tel: +44 (0) 2078696758 / 6768

Email: fgdp@rcseng.ac.uk

www.rcseng.ac.uk/fgdp

May 2005

The Association of Dental Implantology

(ADI) 2005 International Congress

Date: 12-14.05.05

Venue: Edinburgh International Congress

Centre

Tel: +44 (0) 2084875555

Fax: +44(0) 2084875566

Email: adi.uk@btinternet.com

www.adi.org.uk

\section{Pain killer withdrawn}

The Medicines and Healthcare products Regulatory Agency recently announced a phased withdrawal of the commonly prescribed painkiller, co-proxamol.

A recent consultation looking at evidence for the safety and effectiveness of coproxamol found that the benefits of the medicine did not outweigh the risks and that it should be gradually withdrawn from clinical use. Co-proxamol is associated with 300-400 intentional and accidental fatal overdoses each year.

The Chairman of the Committee on Safety of Medicines (CSM), Professor Gordon Duff said, "Co-proxamol will be phased out of the market place gradually to give patients time to discuss their treatment with their doctor and change to a suitable alternative. There is no need for panic or concern and if patients have been taking co-proxamol continuously for a long time they should not stop without consulting

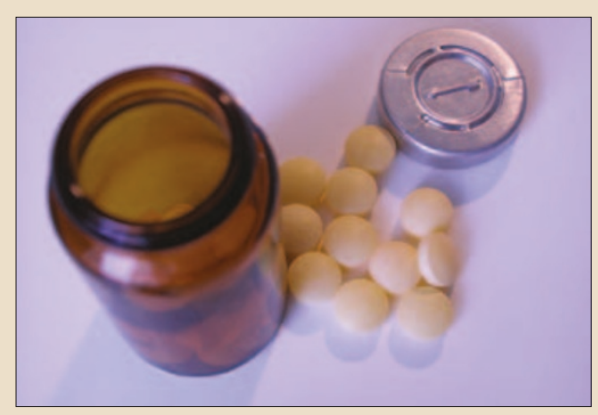
their doctor."

Co-proxamol is available only on prescription and contains a combination of paracetamol and dextropropoxyphene. It is estimated that 1.7 million GP patients per year receive 7.5 million prescriptions for co-proxamol. The MHRA is the executive arm of the UK's Drug Licensing Authority and is responsible for all aspects of the regulation of medicines in the UK.

\section{New Head of Glasgow Dental School}

The University of Glasgow has appointed Professor Jeremy Bagg as Head of Glasgow Dental School with effect from January 2005.

Professor Richard Welbury is the Deputy Head of School, and the Directors of Education and Research are Dr Vince Bissell and Professor Ashraf Ayoub respectively. These changes in personnel correspond with the appointment of Professor David Barlow as Executive Dean of Medicine at Glasgow University and with the first year of the new BDS curriculum, which was launched in September 2004.

The Dental School, as part of the Faculty of Medicine, is the largest Dental School in the UK outside London and provides most of the dental graduates in Scotland. The School is also home to postgraduate taught and research

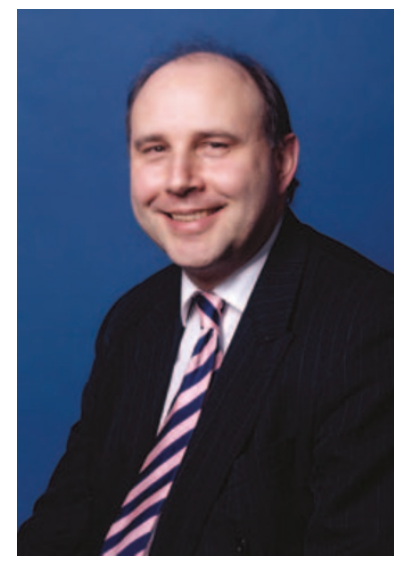
students from the UK and many overseas countries. Information about other recent developments at Glasgow Dental School is available at http://www.gla.ac.uk/schools/dental.

\section{BDJ Collections}

The $B D J$ Collections section of the $B D J$ s website contains a huge topic-specific archive of articles published in the British Dental Journal since 1970. Launched in Autumn of last year, the Collection is the result of an initiative to create a vast resource for $B D J$ readers to be able to access any article published in the Journal

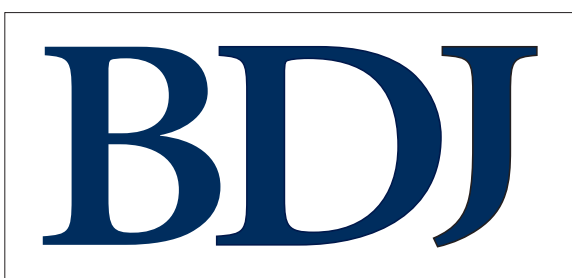
by subject area, from one single point on the website, making it much easier and quicker to obtain the information needed.

It contains full text from 1999, and abstracts from 1988. Online subscribers and BDA members can access it via the $B D J$ or BDA website and non-subscribers can purchase individual articles online.

The $B D J$ Collections are already one of the most popular pages on the $B D J$ 's website, attracting around 22,000 page impressions a month and can be found on www.bdj.co.uk. 


\section{National Smile Week}

The British Dental Health Foundation has announced the theme and dates for this year's National Smile Week, and is urging dentists to get involved by organising an event.

Now in its 29th year, this year's event will run from Sunday, May 15 to Saturday, May 21. Using the tagline 'Talking Teeth', the campaign will centre on the theme of Friends and Communication - encouraging the profession and the public to pass on oral health messages to those around them.

The aim of National Smile Week is to provide simple, practical oral health information to as many people as possible, and the Foundation hopes that the theme will encourage dentists around the country to get involved

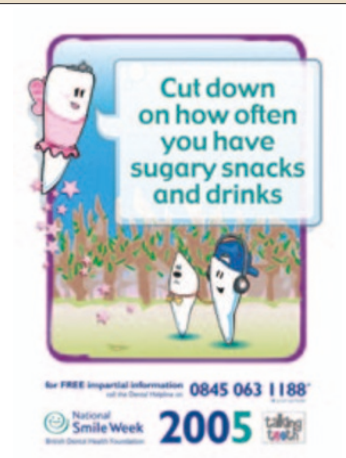
in passing this advice on to their patients.

For this year's campaign, the Foundation is providing a free six-page guide called The Event Organiser. The guide contains oral health information relevant to this year's campaign, tips on organising a successful event and possible event ideas. For your free copy please contact the Foundation on 0870770 4014. Event organiser's will also receive a National Smile Week Resources Catalogue, which cotains products designed specifically for this year's event.

Dr Nigel Carter, chief executive of the Foundation, commented, "It is a well-known fact that dentists do not get the chance to spend as much time as they would like speaking to their patients. However, a well-placed display or a word of advice from a dentist can go a long way towards persuading someone to take a look at their oral health routine. National Smile Week is the ideal time for them to take a step back and remind their patients of their key oral health needs."

\section{Mercury emissions clampdown announced}

Measures to cut by half the amount of toxic mercury which crematoria release into the atmosphere were announced by the government recently.

According to the Department for Environment, Food and Rural Affairs, crematoria are estimated to be responsible for up to 16 percent of all UK emissions of mercury, from fillings in teeth. Mercury emissions are predicted to rise by two-thirds by 2020 unless action is taken.

The new government statutory guidance means that all crematoria should install equipment to cut mercury emissions by 50 percent by 2012 .

New crematoria should be fitted with mercury control equipment, but those conducting fewer than 750 cremations a year have until 2012 to meet the new requirements.

Other countries including Austria, Belgium, Germany, Holland, Norway, Sweden and Switzerland have taken steps to regulate mercury emissions from crematoria.

Britain has also signed up to an international treaty, the UN Heavy Metals Protocol, which aims to cut down on emissions of harmful metals, including mercury, and has already achieved one of its obligations by reducing emissions of mercury below 1990 levels, from 31.6 tonnes, to 8 tonnes in 2002.

Mercury, which accumulates in the air and in water, can harm the brain, kidneys, nervous system and unborn children.

\section{New constitution}

The Association of British Academic Oral and Maxillofacial Surgeons (ABAOMS) has recently agreed a new constitution and has elected officers. The new secretary of the Association is Dr Richard Oliver from Manchester, and the new treasurer is Dr John Marley from Belfast.

The organisation has existed for over twenty years, initially as the 'University Teachers of Oral and Maxillofacial Surgery' and holds an annual three day meeting to discuss research and issues affecting teaching and training within the speciality.

Its sixty five members, mostly staff working in academic units associated with dental schools and hospitals, play a central role in teaching oral and maxillofacial surgery to undergraduates and postgraduates, and in undertaking research programmes into clinical surgical problems.

For further information contact: richard.j.oliver@manchester.ac.uk 